\title{
Implementasi Perlakuan Akuntansi Aset Biologis Berbasis PSAK 69 yang Berlaku Efektif 1 Januari 2018 pada Perusahaan Perkebunan (Studi Kasus PT.PP London Sumatera Indonesia,Tbk)
}

\author{
Yuni Rachmawati', Amanda Oktariyani'2, Ermina ${ }^{3}$, \\ 1Jurusan Akuntansi, Universitas Tridinanti Palembang \\ Email: yunirachmawati@univ-tridinanti.ac.id \\ 2 Jurusan Akuntansi, Universitas Tridinanti Palembang \\ Email: Amanda oktariyani@univ-tridinanti.ac.id \\ ${ }^{3}$ Jurusan Akuntansi, Universitas Tridinanti Palembang \\ Email : erminabiring@yahoo.com
}

\begin{abstract}
Biological Assets in plantation industry has increasing in value through biological transformation. This different characteristic allow the information to be presented more biased than others industries. PSAK 69Agricultur authorized by Dewan Standar Akuntansi Keuangan (DSAK) and effective per 1 Januari 2018, require all plantation industries to use the standard for the December 31 financial statements. PT PP London Sumatera Indonesia,Tbk as a leading and rapidly growing company was a strong reason for the selection of this research object. The purpose of this research was to analyze how to adopt biological assets based on PSAK 69. This research used library studies and field research and analyze using descriptive qualitative. The result show that PT PP London Sumatera Indonesia,Tbk have made recognition, measurement and reporting based on PSAK 69 except in biological assets depreciation.
\end{abstract}

Keywords: Biological Asset, PSAK 69, Agriculture

\begin{abstract}
Abstrak
Aset biologis pada industri perkebunan mengalami peningkatan nilai melalui transformasi biologis. Karakteristik yang berbeda ini memungkinkan informasi dapat disajikan lebih bias dibandingkan dengan perusahaan yang bergerak dibidang lain. Disahkannya PSAK 69-Agrikultur oleh Dewan Standar Akuntansi Keuangan (DSAK) dan berlaku efektif per 1 Januari 2018, mengharuskan semua perusahaan perkebunan menggunkan standar tersebut untuk laporan keuangan periode 31 Desember 2018 ini. PT PP London Sumatera Indonesia,Tbk, sebagai perusahaan perkebunan terkemuka yang telah lama berdiri dan berkembang pesat menjadi alasan kuat pemilihan objek penelitian. Tujuan penelitian ini untuk menganalisa bagaimana perlakuan aset biologis berdasarkan PSAK 69. Penelitian ini menggunakan studi kepustakaan dan penelitian lapangan, serta dianalisa menggunakan metode deskriptif kualitatif. Hasil penelitian menyatakan bahwa PT PP London Sumatera Indonesia,Tbk telah melakukan pengakuan,pengukuran dan pelaporan terhadap aset biologisnya sesuai dengan PSAK 69, kecuali untuk depresiasi aset biologis.
\end{abstract}

Kata Kunci : Aset Biologis, PSAK 69, Agrikultur 
PENDAHULUAN

Indonesia sebagai Negara agraris, memiliki potensi yang besar dalam bidang agrikultur. Sektor agrikultur telah mampu menyerap 38\% tenaga kerja dan menyumbang 13\% dalam perekonomian Indonesia, bahkan sektor ini memiliki peranan dalam menjaga ketahanan pangan nasional (BKPM, 2011). Agrikultur di Indonesia mencakup lima subsektor yaitu subsektor pertanian rakyat, subsektor perkebunan, subsektor kehutanan, subsektor peternakan dan subsektor perikanan. Salah satu subsektor yang memegang peranan penting adalah subsektor perkebunan (Suwarto et al,2014). Subsektor ini menyediakan lebih dari 19,4 juta lapangan pekerjaan bagi penduduk Indonesia (Murjoko, 2017).

Subsektor perkebunan merupakan salah satu penyumbang devisa terbesar Negara yang memberikan kontribusi positif melalui peningkatan ekspor. Kelapa sawit merupakan komoditas dengan volume eskpor terbesar dilanjutkan karet, kelapa, kopi, dan kakao (Murjoko,2017). Pakistan, India, Belanda dan Tiongkok merupakan negara tujuan ekspor.

Industri perkebunan memiliki karakteristik khusus yang membedakannya dengan sektor lain, yaitu pada aset biologisnya. Aset biologis memiliki karakteristik yang unik, karena terjadi kenaikan nilai aset melalui proses pertumbuhan atau dikenal dengan istilah transformasi biologis. Transformasi biologis (biological transformation) terdiri dari proses pertumbuhan, degenerasi, produksi, dan prokreasi yang mengakibatkan perubahan kualitatif atau kuantitatif aset biologis.

Karakteristik aset biologis yang unik dan berbeda inilah, memungkinkan informasi dapat disajikan lebih bias dibandingkan dengan perusahaan yang bergerak dibidang lain, terutama dalam pengukuran, penyajian dan pengungkapan aset tetapnya yang berupa aset biologis (Ridwan, 2011).

Tidak adanya keseragaman dalam standar pelaporan akuntansi biologis akan menimbulkan keberagaman pengungkapan, tidak dapat diperbandingkan antar perusahaan yang sejenis serta dapat menyesatkan pengguna laporan keuangan (Tang and Gao,2013).

Laporan keuangan harus dibuat sesuai dengan standar akuntansi yang berlaku secara global agar dapat diperbandingkan dengan laporan keuangan dengan perusahaan multinasional sejenis. Adanya keseragaman penyajian laporan keuangan sangat dibutuhkan dalam proses pengambilan keputusan ekonomi bagi investor,calon investor dan stakeholders lainnya.

Aset biologis diadopsi dari Internasional Accounting Standards (IAS) 41 yaitu Agricultur. IAS 41 menetapkan standar akuntansi untuk kegiatan pertanian, pengelolaan transformasi biologis atas aset biologis (tanaman dan hewan hidup) ke dalam hasil pertanian (hasil panen perusahaan aset biologis).

Sebelum diadopsinya IAS 41, Laporan Keuangan perusahaan agrikultur masih menggunakan standar umum yaitu PSAK 1: penyajian laporan keuangan, PSAK 14: persediaan, PSAK 16: aset tetap, PSAK 48: penurunan nilai Aktiva, PSAK 32: Kehutanan, SE Bapepam No.SE-02/PM/2002 yang melakukan pengukuran aset biologis menggunakan biaya perolehan (cost model). Namun kelemahan penggunaan biaya perolehan yaitu tidak dapat memperlihatkan nilai yang sesungguhnya karena aset dicatat hanya sebesar biaya yang dikeluarkan. 
Indonesia mulai mengadobsi IAS 41 yang telah menggunakan nilai wajar untuk aset biologis sejak tahun 2014 dan berlaku efektif per 1 Januari 2016. Kemudian, Dewan Standar Akutansi Keuangan (DSAK) melakukan konvergensi IAS 41 ke PSAK 69 sejak tahun 2015 dan mengesahkan PSAK 69 efektif per 1 Januari 2018. Demikian artinya laporan keuangan yang disajikan oleh semua perusahaan perkebunan periode 31 Desember 2018 ini sudah harus menggunakan PSAK 69.

Penelitian mengenai aset biologis telah banyak dilakukan sebelumnya seperti Rianto (2012), Amanah(2015), Tang(2013), Bahri(2015), Dewi(2017) namun masih menggunakan IAS 41 sedangkan Maghiroh (2017) menggunkan ED PSAK 69. Standar keuangan, PSAK 69 ini berlaku efektif per 1 Januari 2018 artinya untuk seluruh perusahaan perkebunan per 31 Desember 2018 ini wajib menggunakan PSAK 69. PT PP London Sumatera Indonesia,Tbk sebagai perusahaan perkebunan yang telah lama berdiri dan berkembang pesat telah mengikuti perkembangan tersebut.

\section{Kajian Literatur \\ Teori Regulasi}

Teori ini berpendapat bahwa dibutuhkan aturan-aturan atau ketentuan dalam akuntansi. Regulasi adalah suatu cara yang digunakan untuk mengendalikan masyarakat dengan aturan tertentu (Ambarwati,2012). Regulasi terjadi sebagai reaksi terhadap suatu krisis yang tidak dapat diidentifikasi. Pembentukan regulasi terkait dengan beberapa kepentingan dan kepentingan tersebut terkait dengan konsekuensi yang akan diterima pengguna atas pembentukan regulasi (Hendiksen,2005 dalam Hasmi,2013).

Pemerintah dibutuhkan peranannya untuk mengatur ketentuan perusahaan yang diperlukan agar pemakai maupun penyaji mendapatkan informasi yang sama dan seimbang.

\section{Teori Stakeholder}

Teori ini menyatakan bahwa kelangsungan hidup perusahaan tergantung pada dukungan stakeholder yang mempengaruhi atau dapat dipengaruhi oleh aktivitas perusahaan (Ghozali dan Chariri, 2007). Perusahaan dalam menjalankan operasi perusahaannya akan berusaha menyesuaikan diri dengan kebutuhan dari stakeholders. Semakin kuat stakeholders, semakin besar pula kecenderungan perusahaan mengadaptasikan diri dengan kebutuhan dan keinginan stakeholders. Keinginan menyajikan laporan keuangan sesuai standar, yang dapat diperbandingkan tentu merupakan salah satu keinginan stakeholder.

\section{Teori Sinyal}

Teori sinyal menyatakan bahwa perusahaan yang memiliki kualitas baik akan dengan sengaja memberikan signal ke pasar, agar pasar dapat membedakan kualitas perusahaan tersebut dengan perusahaan lainnnya (Hartono, 2005 dalam Adnantara, 2013). Teori ini menjelaskan mengapa perusahaan terdorong untuk memberikan informasi laporan keuangan pada pihak esternal. Hal ini disebabkan karena terdapat asimetri informasi antara perusahaan dan pihak eksternal. Agar dapat mengurangi asimetri informasi yang terjadi manajemen perusahaan akan 
ISSN 2657-1080

ISSN 1858-3687

Akuntansi dan Manajemen Vol.14, No.2, 2019

memberikan sinyal kepada pengguna laporan keuangan. Teori sinyal ini berupa informasi mengenai kondisi keuangan perusahaan kepada pemilik atau pihak yang berkepentingan lainnya. Teori sinyal yang diberikan dapat dilakukan melalui pengungkapan informasi akuntansi seperti laporan keuangan. Teori sinyal menunjukan pentingnya informasi yang dikeluarkan oleh manajemen perusahaan terhadap keputusan bisnis dari investor dan kreditor. Teori sinyal berakar pada teori akuntansi prakmatik yang memusatkan perhatian pada pengaruh informasi terhadap perilaku pemakaian informasi (Soewarjono,2005).

\section{Teori Ligitimasi}

Teori legitimasi berpendapat bahwa organisasi selalu berusaha untuk meyakinkan bahwa kegiatan yang mereka lakukan berada pada lingkup dan norma yang bisa diterima oleh lingkungan sosial tempat mereka beroperasi. Teori ini didasari oleh anggapan bahwa terdapat kontrak sosial antara organisasi dan lingkungan sosial yang menuntut agar organisasi melaporkan kegiatan mereka secara sukarela bila pihak manajemen memandang bahwa kegiatan tersebut diharapkan oleh masyarakat (Guthrie and Parker, 1989 dalam Hui and Bowrey, 2008).

\section{Sejarah Standar Akuntansi untuk Aset Biologis}

Belum adanya standar akuntansi khusus yang membahas mengenai aset biologis, membuat perusahaan perkebunan menggunakan standar umum akuntansi keuangan yaitu PSAK 1, PSAK 14:persediaan, PSAK 16 :aset tetap, PSAK 48 :penurunan nilai Aktiva, PSAK 32 :Kehutanan, SE Bapepam No.SE-02/PM/2002 yang pengukuran menggunakan biaya perolehan. Namun penggunaan biaya perolehan tidak dapat memperlihatkan nilai yang sesungguhnya karena aset dicatat hanya sebesar biaya yang dikeluarkan. Kuantitas aset biologis tidak hanya berdasarkan aktivitas jual beli, tetapi berdasarkan proses pembentukan, pertumbuhan dan kematian yang tidak dapat dihasilkan dengan menggunakan nilai historis.(Pratiwi,2017).

Internasional Accounting Standards Committee (IASC) pada Februari 2001 telah mempublikasikan dalam IFRS, perlakuan akuntansi bagi aset biologis diatur dalam International Accounting Standard (IAS) 41 yang melingkupi tentang akuntansi bagi sektor usaha agrikultur. IAS 41 terakhir telah direvisi dan dikeluarkan tahun 2009. Indonesia mulai mengadobsi IAS 41 tahun 2014 dan berlaku efektif per 1 Januari 2016. IAS 41 telah menggunakan nilai wajar untuk aset biologis. Dewan Standar Akutansi Keuangan (DSAK) melakukan konvergensi IAS 41 ke PSAK 69. Explosure Draft (ED) PSAK 69 Agrikultur disahkan pada Desember 2015. Setelah melakukan Public Hearing, PSAK 69 disahkan dan efektif per 1 Januari 2018.

\section{Aset Biologis}

\section{Pengertian Aset Biologis}

Aset biologis adalah jenis aset berupa hewan dan tumbuhan hidup. Aset biologis merupakan aset yang sebagian besar digunakan dalam aktivitas usaha dalam rangka manajemen transformasi biologis dari aset biologis untuk 
ISSN 2657-1080

ISSN 1858-3687

Akuntansi dan Manajemen Vol.14, No.2, 2019

menghasilkan produk yang siap dikomsumsi atau masih membutuhkan proses yang lebih lanjut. Berdasarkan PSAK 69 transformasi biologis terdiri dari proses pertumbuhan (peningkatan kuantitas atau perbaikan kualitas hewan atau tanaman), degenerasi (penurunan kuantitas atau oenurunan kualita hewan atau tanaman) dan prokreasi (penciptaan hewan atau tanaman hidup tambahan) yang mengakibatkan perubahaan kualitatif atau kuantitatif aset biologis (PSAK 69, 2015). Terkait dengan perlakuan akuntansi aset biologis adalah bagaimana pengakuan,pengukuran,serta pengungkapan aset biologis.

\section{Pengakuan Aset Biologis}

PSAK 69 mengatur, Entitas mengakui aset biologis atau produk agricultur jika dan hanya jika :

a. Entitas mengendalikan aset biologis sebagai akibat dari peristiwa masa Besar kemungkinan manfaat ekonomis aset di masa datang akan mengalir ke entitas, biasanya dinilai dengan mengukur atribut fisik; dan

b. besar kemungkinan manfaat ekonomik masa depan yang terkait dengan aset biologis tersebut akan mengalir ke entitas; dan

c. nilai wajar atau biaya perolehan aset biologis dapat diukur secara andal

Aset biologis dalam laporan keuangan dapat diakui sebagai aset lancer maupun aset tidak lancar sesuai dengan jangka waktu transformasi biologis dari aset biologis yang bersangkutan. Aset biologis diakui ke dalam aset lancar ketika masa manfaat atau masa transformasi biologisnya kurang dari atau sampai dengan 1 (satu) tahun dan diakui sebagai aset tidak lancar jika masa manfaat atau masa transformasi biologisnya lebih dari 1 (satu) tahun

\section{Pengukuran Aset Biologis}

Aset biologis berdasarkan PSAK 69, harus diukur pada saat pengakuan awal dan pada setiap akhir periode pelaporan pada nilai wajarnya dikurangi dengan biaya menjual. Kecuali untuk kasus yang dideskripsikan dalam paragraf 30 dimana nilai wajar tidak dapat diukur secara andal. nilai wajar atau biaya perolehan aset biologis dapat diukur secara andal.

Produk agrikultur yang dipanen dari aset biologis milik entitas diukur pada nilai wajar dikurangi biaya untuk menjual pada titik panen. Pengukuran seperti ini merupakan biaya pada tanggal tersebut ketika menerapkan PSAK 14: Persediaan atau Pernyataan lain yang berlaku.

\section{Pengungkapan Aset Biologis}

Dalam PSAK 69, Entitas dianjurkan untuk memberikan deskripsi kuantitatif dari setiap kelompok aset biologis, membedakan antara aset biologis yang dapat dikonsumsi dan aset biologis produktif,atau antara aset biologis menghasilkandan yang belum menghasilkan, sesuai keadaan aset biologis. Sebagai contoh, entitas dapat mengungkapkan jumlah tercatat aset biologis yang dapat dikonsumsi dan aset biologis produktif berdasarkan kelompok. Entitas selanjutnya dapat membagi jumlah tercatat tersebut antara aset yang telah menghasilkan dan belum menghasilkan. 
ISSN 2657-1080

ISSN 1858-3687

Akuntansi dan Manajemen Vol.14, No.2, 2019

Penelitian Terdahulu

Penelitian terkait aset biologis perusahaan perkebunan telah banyak dilakukan, namun peneliti terdahulu menggunakan IAS 41 dan ED PSAK 69 sedangkan pada penelitian ini menggunakan PSAK 69 yang berlaku efektif per 1 Januari 2018.

\begin{tabular}{|c|c|c|c|c|}
\hline NO & Nama Peneliti & Judul Penelitian & $\begin{array}{l}\text { Tahun } \\
\text { Penelitian }\end{array}$ & $\begin{array}{l}\text { Standar } \\
\text { Keuangan }\end{array}$ \\
\hline 1 & Rianto, Agus Budi Lister & $\begin{array}{l}\text { Analisis Pengakuan, Pengukuran dan } \\
\text { Penyajian Aset Biologis Menurut Standar } \\
\text { Akuntansi yang Berlaku di Indonesia dan } \\
\text { Menurut IAS } 41 \text { : Agriculture, StudiKasus: PT } \\
\text { Kelantara Sakti. }\end{array}$ & 2012 & IAS 41 \\
\hline 2 & Amanah,Dian dan Riska & $\begin{array}{l}\text { Analisis Perbandingan Perlakuan Akuntansi } \\
\text { Aset Biologis pada Industri Perkebunan (Studi } \\
\text { Kasus pada PT Sampoerna Agro Tbk dan PT } \\
\text { Dharma Satya Nusantara Tbk). }\end{array}$ & 2015 & IAS 41 \\
\hline 3 & Tang, Qing-wan; Gao, Peng. & $\begin{array}{l}\text { Research on Information Disclosure of } \\
\text { Biological Assets of Agricultural Listed } \\
\text { Company in China. }\end{array}$ & 2013. & IAS 41 \\
\hline 4 & Bahri, Syefrica Wahyulia & $\begin{array}{llll}\text { Evaluasi Penilaian Aset } & \text { Biologis } & \text { Dan } \\
\text { Pengaruhnya Terhadap } & & \\
\text { Laporan Keuangan".Studi } & \text { Kasus } & \text { Pada } \\
\text { M.P.Evans Group PLC) } & & \\
& & \end{array}$ & 2015 & IAS 41 \\
\hline 5 & Dewi,NI Wayan dan Gusti Ayu & $\begin{array}{l}\text { Analisis Sistem Akuntansi Aset Biologis } \\
\text { Perusahaan Akuakultur (Studi kasus Pada CV } \\
\text { Dewata Laut). }\end{array}$ & 2017 & IAS 41 \\
\hline 6 & Maghfiroh, Siti & $\begin{array}{l}\text { Perlakuan Aset Biologis Pada Industri } \\
\text { Perkebunan Berdasarkan IAS } 41 \text { Agricultured } \\
\text { dan ED PSAK } 69 \text { Agrikultur. Studi Pada } \\
\begin{array}{l}\text { PT.Perkebunan Nusantara XII } \\
\text { Surabaya }\end{array}\end{array}$ & 2017 & $\begin{array}{l}\text { IAS } 41 \text { dan ED } \\
\text { PSAK } 69\end{array}$ \\
\hline
\end{tabular}

Sumber : Data Sekunder diolah penulis, 2019

\subsection{Kerangka Berpikir}

Kerangka berpikir dari penelitian ini dapat terlihat pada Gambar 1 berikut: 
Gambar 1

Kerangka Berpikir

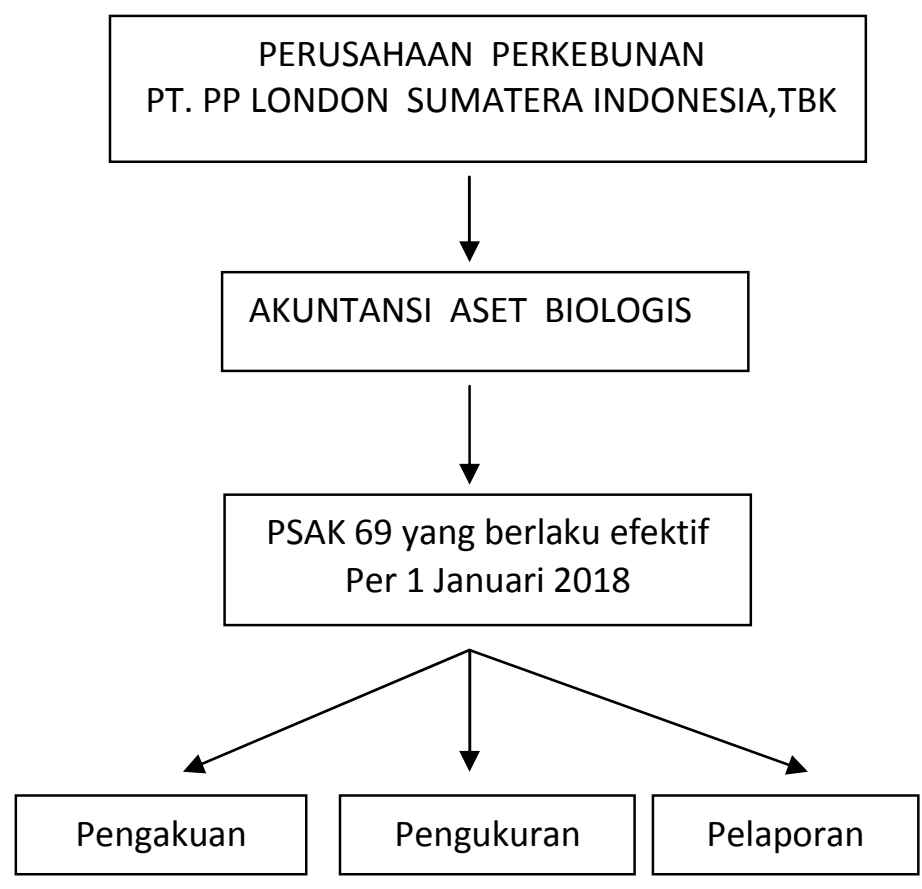

Sumber : Data diolah penulis,2019

\section{Metode Penelitian}

\section{Objek Penelitian}

Penelitian ini menggunakan PT. PP London Sumatera Indonesia, Tbk sebagai objek penelitian dengan dasar pertimbangan umur perusahaan berdiri dan sudah melakukan Initial Public Offering sejak tahun 1996. PT. PP London Sumatera Indonesia, Tbk telah mulai melakukan perubahan menuju PSAK 69 yang berlaku efektif per 1 Januari 2018 dalam penyajian laporan keuangannya.

\section{Jenis dan Sumber data}

Penelitian ini merupakan penelitian kualitatif yang mengukur perlakuan akuntansi aset biologis pada objek penelitian dibandingkan dengan standar akuntansinya yaitu PSAk 69. Data yang digunakan adalah data primer dan sekunder berupa Laporan Keuangan dan Catatan Atas Laporan Keuangan PT.PP London Sumatera Indonesia,Tbk tahun 2018, serta sumber data lain baik yang dipublikasikan maupun yang tidak dipublikasikan.

\section{Teknik Pengumpulan data}

Teknik pengumpulan data yang digunakan peneliti adalah penelitian kepustakaan dan penelitian lapangan meliputi observasi, wawancara kepada manajer dan atau staf keuangan. Selain itu juga menggunakan teknik pengumpulan data dengan dokumentasi pada PT.PP London Sumatera Indonesia,Tbk. 


\section{Teknik Analisa Data}

Pada penelitian ini, menggunakan teknik analisa data deskriptif kualitatif dan analisa kualitatif komparatif. Deskriptif kualitatif bertujuan untuk memberikan gambaran awal mengenai pengukuran, pengakuan, dan pengungkapan aset biologis pada perusahaan perkebunan melalui studi kasus PT PP London Sumatera Indonesia Tbk. Analisa Kualitatif Komparatif dengan membandingkan perlakuan akuntansi aset biologis pada objek dengan PSAK 69.

\section{Metode Analisis Data}

Metode analisis data yang digunakan dalam penelitian ini adalah analisis kualitatif, yaitu dengan memberikan gambaran awal mengenai pengukuran, pengakuan, dan pengungkapan aset biologis pada perusahaan perkebunan melalui studi kasus PT PP London Sumatera Indonesia Tbk.

\section{HASIL DAN PEMBAHASAN}

\section{Deskripsi Objek Penelitian}

PT Perusahaan Perkebunan London Sumatra Indonesia Tbk ("Perusahaan”) yang selanjutnya disebut Lonsum, didirikan pada tahun 1962. Perusahaan memulai operasi komersialnya pada tahun 1963 dan bergerak di bidang usaha perkebunan yang berlokasi di Sumatera Utara, Sumatera Selatan, Jawa, Kalimantan Timur, Sulawesi Utara, dan Sulawesi Selatan dengan lahan yang ditanami seluas 115.409 hektar. Produk utama adalah minyak kelapa sawit ("MKS") dan karet, serta kakao, teh, dan benih kelapa sawit dalam kuantitas yang lebih kecil.

Perusahaan berkantor pusat di Jakarta Selatan dengan kantor-kantor cabang operasional berlokasi di Palembang, Medan, Makasar dan Samarinda. PT PP Lonsum tidak hanya mengelola perkebunannya sendiri, namun juga mengembangkan perkebunan pada lahan yang dimiliki petani kecil setempat atau dikenal dengan perkebunan plasma yang sesuai dengan pola perkebunan "inti-plasma" yang dipilih pada saat Perusahaan melakukan ekspansi perkebunan.

\section{Pengakuan, Pengukuran dan Penggolongan Aset Biologis Pengakuan}

Aset biologis berupa tanaman perkebunan pada PT Lonsum yaitu terdiri dari Tandan Buah Segar (TBS), karet, dan benih kelapa sawit. Tanaman produktif utama Kelompok Usaha adalah kelapa sawit dan karet. Tanaman perkebunan PT Lonsum dikelompokkan menjadi dua kelompok yaitu Tanaman Produktif Belum Menghasilkan (TBM) dan Tanaman Produktif Menghasilkan (TM).

Tanaman produktif merupakan tanaman hidup yang digunakan dalam produksi ataupun dalam penyediaan produk agrikultur. Tanaman produktif diharapkan mampu menghasilkan produk untuk jangka waktu lebih dari satu tahun atau satu periode. Dalam kondisi normal operasional, tanaman produktif sangat jarang dijual sebagai produk agrikultur. Namun tidak menutup kemungkinan terjadinya penjualan yaitu sesekali saat penjualan sisa. 
ISSN 2657-1080

ISSN 1858-3687

Akuntansi dan Manajemen Vol.14, No.2, 2019

Tanaman Produktif Belum Menghasilkan diakui sebagai aset tidak lancar. Tanaman produktif belum menghasilkan akan direklasifikasi menjadi Tanaman Produktif Menghasilkan pada saat tanaman telah dinyatakan mampu menghasilkan produk agrikultur dan dapat dipanen. Antar jenis tanaman produktif membutuhkan waktu yang berbeda untuk dapat menghasilkan produk agrikultur. Umumnya tanaman produktif kelapa sawit lebih cepat menghasilkan dibandingkan tanaman karet. Selain umur tanaman produktif, pertumbuhan vegetativ dan taksiran manajemen juga menjadi dasar klasifikasi aset biologis pada industri perkebunan ini.

Tabel 1

Klasifikasi Tanaman Produktif Menghasilkan

\begin{tabular}{|c|c|c|c|}
\hline & Indikator & Kelapa sawit & Karet \\
\hline 1 & Pertumbuhan vegetatif & $\begin{array}{l}\text { Dikatakan Tanaman Produktif Menghasilkan } \\
\text { Jika } 80 \% \text { dari jumlah seluruh pohon per blok } \\
\text { telah menghasilkan tandan buah, atau } \\
\text { - jika dua lingkaran tandan telah matang, atau } \\
\text { - berat rata-rata per tandan telah mencapai } \\
\text { minimal } 3 \mathrm{~kg}\end{array}$ & $\begin{array}{l}\text { Dikatakan Tanaman } \\
\text { Menghasilkan jika } 80 \% \text { dari jumlah } \\
\text { seluruh pohon per blok sudah dapat } \\
\text { dideres } \\
\text {-mempunyai ukuran lilitan batang minimal } \\
45 \mathrm{~cm} \text { yang diukur pada ketinggian } 1 \\
\text { meter dari pertautan okulasi dan tebal } \\
\text { kulit minimal } 7 \mathrm{~mm} \text {. }\end{array}$ \\
\hline 2 & Jangka waktu & $\begin{array}{l}\text { Membutuhkan waktu } 3-4 \text { tahun sejak } \\
\text { penanaman bibit di area perkebunan untuk } \\
\text { menjadi tanaman produktif. }\end{array}$ & $\begin{array}{l}\text { Membutuhkan waktu } 5-6 \text { tahun untuk } \\
\text { menjadi tanaman produktif. }\end{array}$ \\
\hline
\end{tabular}
Sumber: Data sekunder yang diolah Penulis, 2019

Pengelompokan yang dilakukan PT PP London Sumatera Indonesia,Tbk telah sesuai dengan PSAK 69 paragfraf 15 mengenai pengukuran nilai wajar untuk produk agrikultur atau aset biologis yang didukung dengan pengelompokan aset biologis sesuai dengan atribut yang signifikan, seperti usia atau kualitas.

Dalam aktivitas agrikultur, aset biologis mengalami proses yang disebut transformasi biologis yang meliputi 1)proses pertumbuhan aset biologis tumbuh menjadi lebih besar, 2)proses degenerasi dimana aset biologis berkembang, 3)proses produksi dimana aset telah menghasilkan produk, dan 4)proses prokreasi yaitu pertumbuhan aset biologis sampai pada titik tertentu kemudian menghasilkan. Adanya transformasi biologis ini mengakibatkan perubahan kualitatif dan kuantitatif yang menyebabkan perbedaan nilai setiap asetnya.

Setelah memenuhi kualifikasinya, selanjutnya Tanaman Produktif Menghasilkan diakui sebagai aset tidak lancar. PT PP London Sumatera Indonesia,Tbk mencatat tanaman menghasilkan dengan nama akun "aset biologis" pada Laporan Posisi Keuangan Konsolidasian. Tanaman menghasilkan diukur pada biaya perolehan setelah dikurangi akumulasi penyusutan dan akumulasi rugi penurunan nilai.

Oleh karena Tanaman Produktif Menghasilkan telah mampu memberikan kontribusi manfaat kepada perusahaan berupa kemampuan menghasilkan produk agrikultur maka amortisasi penyusutan dilakukan untuk mengakui manfaat dari tanaman menghasilakn pada setiap periodenya. 
ISSN 2657-1080

ISSN 1858-3687

Akuntansi dan Manajemen Vol.14, No.2, 2019

Jumlah tercatat tanaman produktif direview apakah mengalami peningkatan ataukah penurunan. Dikatakan terjadi penurunan nilai ketika terdapat keadaan atau peristiwa yang mengindikasikan bahwa jumlah tercatat tidak terealisasi seluruhnya. Ketika terjadi pemulihan atas penurunan nilai maka akan diakui sebagai keuntungan periode terjadinya sebagai pendapatan non usaha atau dikenal dengan other Comprehensive Income (OCI). Jumlah tercatat komponen dari suatu tanaman produktif akan dihentikan pengakuannya yaitu ketika dilepaskan atau tidak terdapat manfaat ekonomi masa depan yang diharapkan dari penggunaan maupun pelepasan aset biologis tersebut.

Terkait dengan biaya pengurusan legal hak atas tanah dalam bentuk Hak Guna Usaha ("HGU"), Hak Guna Bangunan ("HGB"), dan Hak Pakai ("HP") ketika tanah diperoleh pertama kali, diakui sebagai bagian dari biaya perolehan tanah pada akun "Aset Tetap" dan tidak diamortisasi. Sementara biaya pengurusan atas perpanjangan atau pembaruan legal hak atas tanah dalam bentuk HGU, HGB, dan HP diakui sebagai bagian dari akun "Beban Tangguhan" pada laporan posisi keuangan konsolidasian dan diamortisasi sepanjang mana yang lebih pendek antara umur hukum hak dan umur ekonomis tanah.

\section{Pengukuran}

Tanaman Produktif Belum Menghasilkan dinyatakan sebesar biaya perolehan yang meliputi akumulasi biaya persiapan lahan, penanaman bibit, pemupukan, pemeliharaan dan alokasi biaya tidak langsung lainnya sampai dengan saat tanaman yang bersangkutan dinyatakan menghasilkan dan dapat dipanen.Biaya pinjaman dan biaya-biaya lainnya yang terjadi sehubungan dengan pendanaan pengembangan Tanaman Produktif Belum Menghasilkan juga dikapitalisasi pada Tanaman Produktif Belum Menghasilkan. Kapitalisasi beban pinjaman tersebut baru berakhir ketika pohonpohon telah menghasilkan dan siap untuk dipanen. Tanaman Belum Menghasilkan tidak diamortisasi hingga reklasifikasi menjadi Tanaman Menghasilkan dilakukan.

Ketika reklasifikasi menjadi Tanaman Produktif Menghasilkan terjadi, beban penyusutan mulai diperhitungkan. PT PP London Sumatera Indonesia,Tbk mengamortisasi aset biologis sesuai masa manfaatnya dengan metode garis lurus. Kelapa sawit dan karet keduanya ditaksir mampu menghasilakn hingga 25 tahun. Umur manfaat aset dan metode penyusutan ini dievaluasi setiap akhir periode pelaporam dan jika dianggap perlu akan disesuaikan secara prospektif.

Nilai wajar atas produk agrikultur kelapa sawit dan karet ditentukan berdasarkan harga pasar terkait yang diterapkan terhadap estimasi volume produksi terhadap harga pasar yang berlaku pada tanggal pelaporan. Dalam menentukan nilai wajar dikurangi biaya untuk menjual, digunakan harga penawaran pasar terakhir, jika tersedia. Jika tidak terdapat transaksi tersebut, Kelompok Usaha menggunakan model penilaian yang sesuai untuk menentukan nilai wajar aset. Perhitungan-perhitungan ini dikuatkan oleh penilaian berganda atau indikator nilai wajar yang tersedia.

Layaknya sebuah aset, Tanaman Menghasilkan juga bisa mengalami penurunan nilai. Penilaian dilakukan pada setiap akhir tanggal pelaporan, untuk memastikan apakah kembali terjadi penurunan nilai aset biologis ataukah justru harus mengestimasi nilai terpulihkan atas aset biologis tersebut. Penurunan nilai atas aset biologis diakui 
ISSN 2657-1080

ISSN 1858-3687

Akuntansi dan Manajemen Vol.14, No.2, 2019

sebagai kerugian pada periode terjadinya. Tanaman menghasilkan diakumulasikan kerugian dari operasi yang berkelanjutan, jika ada diakui sebagai laba atau rugi sesuai dengan kategori biaya yang konsisten dengan fungsi dari aset yang diturunkan nilainya.

Selain penurunan nilai, kondisi lain yang memungkinkan dicatatnya kerugian adalah ketika aset biologis dilepas atau tidak diharapkan lagi manfaat ekonomi masa depannya. Kondisi ini akan menimbulkan pengakuan dan pengukuran dan pelaporan keuntungan atau kerugian. Besarnya keuntungan atau kerugian ini ditentutkan sebesar selisih antara jumlah hasil pelepasan neto dan jumlah tercatatnya, dan dimasukkan ke dalam laba rugi pada tahun penghentian pengakuan tersebut dilakukan.

Sedangkan untuk beban pemeliharaan tanaman produktif, PT PP London Sumatera Indonesia,Tbk membebankannya pada laba rugi saat periode terjadinya. Beban pemugaran dan penambahan dalam jumlah besar dikapitalisasi pada jumlah tercatat terkait jika besar kemungkinan bagi Kelompok Usaha manfaat ekonomi masa depan menjadi lebih besar dari standar kinerja awal yang ditetapkan sebelumnya dan disusutkan sepanjang sisa masa manfaat aset terkait.

Biaya-biaya tertentu, yang mempunyai masa manfaat lebih dari satu tahun, sehubungan dengan biaya perolehan sistem perangkat lunak, dan beban sehubungan dengan perpanjangan hak atas tanah, ditangguhkan dan diamortisasi selama masa manfaatnya dengan menggunakan metode garis lurus. Bebanbeban ini disajikan dalam akun "Beban Tangguhan" pada laporan posisi keuangan konsolidasian dan dibebankan secara langsung pada usaha periode berjalan sebagai bagian dari akun "Beban Pokok Penjualan" dan "Beban Operasi Lain" pada laporan laba rugi dan penghasilan komprehensif lain konsolidasian.

Pengukuran nilai wajar mengasumsikan bahwa transaksi untuk menjual aset atau mengalihkan liabilitas terjadi: i) Di pasar utama untuk aset atau liabilitas tersebut, atau ii) Jika tidak terdapat pasar utama, di pasar yang paling menguntungkan untuk aset atau liabilitas tersebut.

Tabel 2

Analisa Perbandingan Perlakuan Aset Biologis

PT PP London Sumatera Indonesia,Tbk dengan PSAK 69

\begin{tabular}{|l|l|l|}
\hline \multicolumn{1}{|c|}{ Keterangan } & PT PP London Sumatera Indonesia, & \multicolumn{1}{|c|}{ PSAK 69 } \\
\hline Klasifikasi Aset biologis & $\begin{array}{l}\text { Entitas mengklasifikasi Tanaman } \\
\text { Produktif Belum Menghasilkan dan } \\
\text { Tanaman Produktif Menghasilkan }\end{array}$ & $\begin{array}{l}\text { Mewajibkan entitas untuk } \\
\text { mengklasifikasikan aset biologis } \\
\text { berdasarkan jenis dan umur aset } \\
\text { biologisnya. }\end{array}$ \\
\hline Penyusutan & $\begin{array}{l}\text { Entitas tidak membebankan } \\
\text { penyusutan pada Tanaman Belum } \\
\text { Menghasilkan namu mengakui } \\
\text { penyusutan atau amortisasi pada } \\
\text { Tanaman Produktif Menghasilkan }\end{array}$ & $\begin{array}{l}\text { PSAK tidak mengakui adanya } \\
\text { depresiasi pada agrikultur }\end{array}$ \\
\hline Pengakuan nilai wajar & $\begin{array}{l}\text { Pengukuran nilai wajar } \\
\text { mengasumsikan bahwa transaksi untuk } \\
\text { menjual aset atau mengalihkan } \\
\text { liabilitas terjadi: } \\
\text { i) Di pasar utama untuk aset atau }\end{array}$ & $\begin{array}{l}\text { 1. Harga pasar transaksi terbaru } \\
\text { asalkan belum ada perubahan } \\
\text { yang signifikan antara tanggal } \\
\text { transaksi dan periode akhir } \\
\text { pelaporan. }\end{array}$ \\
\hline
\end{tabular}




\begin{tabular}{|c|c|c|}
\hline & $\begin{array}{l}\text { liabilitas tersebut, atau } \\
\text { ii) Jika tidak terdapat pasar utama, di } \\
\text { pasar yang paling menguntungkan } \\
\text { untuk aset } \\
\text { atau liabilitas tersebut. } \\
\text { Kelompok Usaha menggunakan teknik } \\
\text { penilaian yang sesuai dengan keadaan } \\
\text { dan data } \\
\text { yang memadai tersedia untuk } \\
\text { mengukur nilai wajar, dengan } \\
\text { memaksimalkan masukan (input) yang } \\
\text { dapat diamati (observable) yang } \\
\text { relevan } \\
\text { dan meminimalkan masukan (input) } \\
\text { yang tidak } \\
\text { dapat diamati (unobservable). }\end{array}$ & $\begin{array}{l}\text { 2. Harga pasar untuk aset serupa } \\
\text { dengan penyesuaian } \\
\text { 3. Benchmark seperti kebun yang } \\
\text { dinyatakan per hektar dan nilai } \\
\text { ternak yang dinyatakan per } \\
\text { kilogram }\end{array}$ \\
\hline Keuntungan dan kerugian & $\begin{array}{l}\text { Keuntungan atau } \\
\text { kerugian yang timbul pada pengakuan } \\
\text { awal } \\
\text { produk agrikultur pada nilai wajar } \\
\text { dikurangi } \\
\text { biaya untuk menjual dan dari } \\
\text { perubahan nilai } \\
\text { wajar dikurangi biaya untuk menjual } \\
\text { dari aset } \\
\text { biologis pada setiap tanggal pelaporan } \\
\text { dimasukkan dalam laba rugi pada } \\
\text { tahun } \\
\text { terjadinya. } \\
\text { Keuntungan dan kerugian atas } \\
\text { penilaian kembali aset biologis diakui } \\
\text { pada laporan laba rugi periode } \\
\text { berjalan. Dicatat dengan nama "Rugi } \\
\text { yang timbul dari perubahan nilai wajar } \\
\text { aset biologis". }\end{array}$ & $\begin{array}{l}\text { Keuntungan atau kerugian yang } \\
\text { timbul saat pengakuan awal aset } \\
\text { pada nilai wajar dikurangi biaya-biaya } \\
\text { dimasukkan dalam laporan laba/rugi. } \\
\text { Keuntungan dan kerugian atas } \\
\text { penilaian kembali aset biologis diakui } \\
\text { pada laporan laba rugi periode } \\
\text { berjalan. }\end{array}$ \\
\hline Laporan Laba Rugi & $\begin{array}{l}\text { Karena adanya pengakuan depresiasi } \\
\text { maka berdampak pada penurunan laba } \\
\text { rugi pada tahun berjalan }\end{array}$ & $\begin{array}{l}\text { Tidak mengakui adanya depresiasi } \\
\text { sehingga tidak terdapat akun } \\
\text { akumulasi depresisasi yang } \\
\text { menyebabkan adanya kenaikan } \\
\text { oada laporan laba/rugi }\end{array}$ \\
\hline
\end{tabular}

Sumber : Data sekunder diolah penulis, 2019

\section{Pengungkapan}

Dalam pengungkapan terdapat beberapa hal yang harus diungkapkan, diantaranya a.Rincian jenis dan jumlah aset tanaman yaitu aset tanaman belum menghasilkan dan tanaman menghasilkan.

b. Metode penyusutan/ amortisasi digunakan adalah metode garis lurus.

c. Umur manfaat dan tarif penyusutan yang digunakan. Umur manfaat untuk tanaman kelapa sawit dan karet adalah 25 tahun. 
ISSN 2657-1080

ISSN 1858-3687

Akuntansi dan Manajemen Vol.14, No.2, 2019

d. Jumlah tercatat bruto akumulasi penyusutan/ amortisasi pada akhir dan awal periode.

e. Rekonsiliasi jumlah tercatat akhir dan awal periode menunjukan bahwa:

1) Penambahan

2) Pengurang/pelepasan

3) Penurunan nilai

4) Penyusutan

f. Pengungkapan lainnya

Berdasarkan hasil dari tanaman menghasilkan berupa produk agricultur pada PT Lonsum tersebut setelah dipanen diakui sebagai persediaan, ketika produk agricultur tersebut merupakan produk agricultur yang siap untuk dijual atau merupakan produk agricultur yang digunakan sebagai bahan baku dari proses produksi sebesar biaya perolehan. Produk yang diakui sebagai persediaan pada tanggal pelaporan diukur berdasarkan biaya yang lebih rendah antara biaya perolehan dan nilai realisasi bersih. Biaya perolehan dari produk agricultur diperoleh dari mengkapitalisasi biaya-biaya yang dikeluarkan untuk memanen produk agricultur tersebut siap untuk dijual atau digunakan dalam proses produksi lebih lanjut. Biaya-biaya yang dikapitalisasikan sebagai biaya perolehan dari produk agricultur yaitu biaya angkut hasil panen ke gudang, biaya sortif produk agricultur. dan biaya-biaya lain yang berhubungan langsung dengan proses produk agricultur. Sedangkan nilai realisasi bersih diperoleh dengan taksiran harga wajar penjualan dalam kegiatan usaha normal dikurangi dengan taksiran biaya yang diperlukan untuk melaksanakan penjualan, jika ada.

Selain produk agricultur berupa produk utama tanaman perkebunan, tanaman menghasilkan juga dapat menghasilkan produk sampingan yang tidak dimaksudkan untuk dihasilkan dari suatu proses produksi yang serentak dan mempunyai nilai yang relatif rendah. Produk sampingan tersebut berupa bibit tanaman. Jika bibit tanaman baru maka tanaman tersebut diakui sebagai tanaman belum menghasilkan dan diakui berdasarkan biaya perolehan.

Pada Tabel 3 dapat dilihat pencatatan atas transaksi yang terkait aset biologis.

Tabel 3

Jurnal PT PP London Sumatera Indonesia,Tbk Atas Aktivitas Terkait Aset Biologis

\begin{tabular}{|c|c|c|}
\hline No & Jenis Aktivitas Operasional & $\begin{array}{c}\text { Junal Menurut } \\
\text { PT PP London Sumatera Indonesia,Tbk }\end{array}$ \\
\hline 1 & $\begin{array}{l}\text { Biaya Persiapan lahan untuk penanaman } \\
\text { tanaman baru }\end{array}$ & $\begin{array}{l}\text { Tanaman Belum Menghasilkan (TBM) xxx } \\
\text { Kas/hutang }\end{array}$ \\
\hline 2 & $\begin{array}{l}\text { Pembelian bibit tanaman baru. } \\
\text { (LSIP memiliki bibit sendiri/tidak beli, } \\
\text { sehingga pencatatannya dalam nursery } \\
\text { atau bibitan) }\end{array}$ & $\begin{array}{l}\text { Bibitan } \\
\quad \text { Kas/hutang }\end{array}$ \\
\hline 3 & $\begin{array}{l}\text { Pembelian bahan perlengkapan, seperti } \\
\text { pestisida,pupuk,dll }\end{array}$ & $\begin{array}{l}\text { Material } \\
\text { Kas/hutang }\end{array}$ \\
\hline 4 & $\begin{array}{l}\text { Biaya perawatan rutin sebelum usia } \\
\text { produktif tanaman }\end{array}$ & $\begin{array}{l}\text { Tanaman Belum Menghasilkan (TBM) xxx } \\
\text { Kas/hutang }\end{array}$ \\
\hline
\end{tabular}


ISSN 2657-1080

ISSN 1858-3687

Akuntansi dan Manajemen Vol.14, No.2, 2019

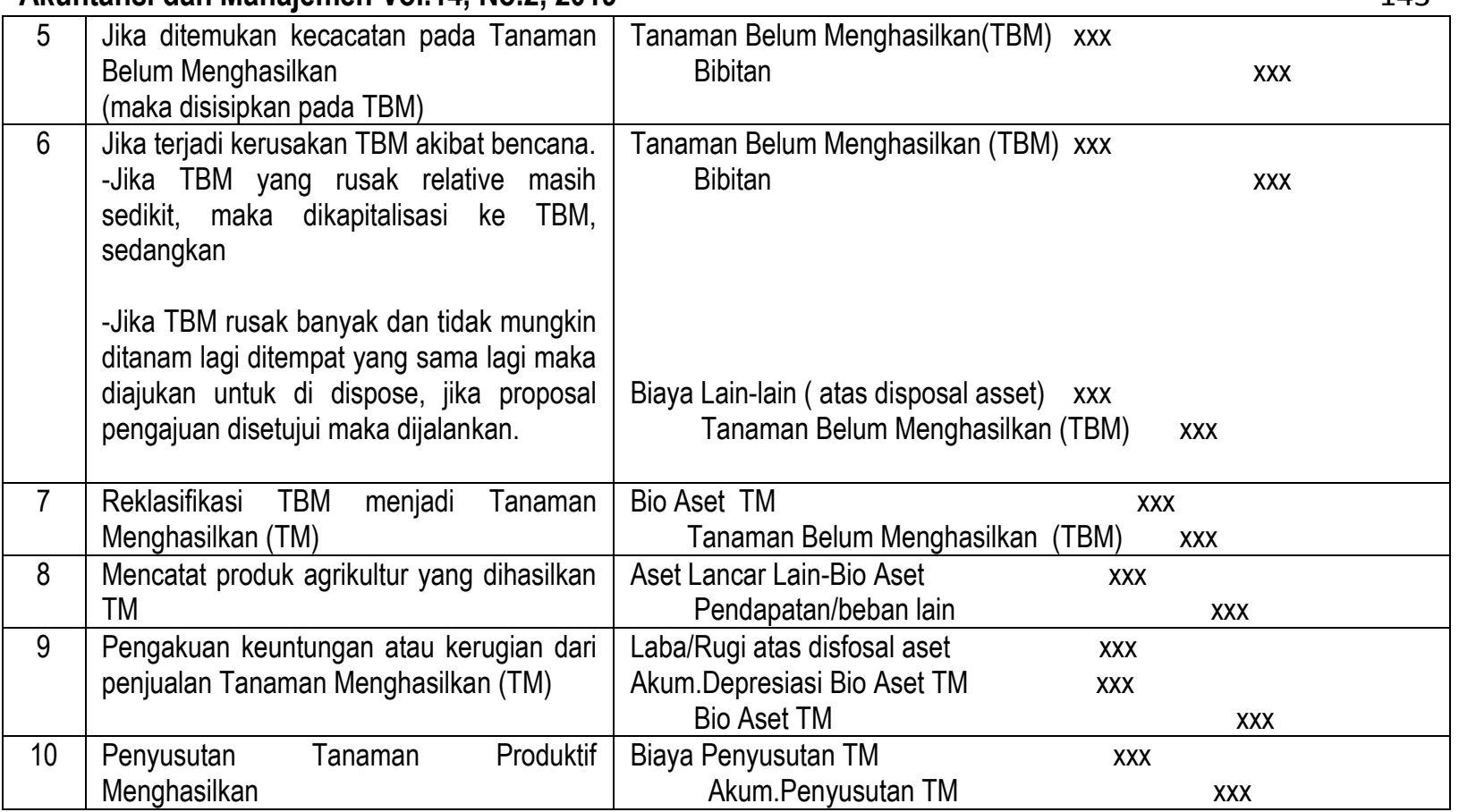

\section{Kesimpulan}

PT London Sumatera Indonesia Tbk, telah menggunakan PSAK 69 sebagai standar perlakuan akuntansi aset biologisnya. Mulai dari pengakuan aset, pengukuran hingga pelaporan aset biologis telah sesuai PSAK 69, namun terkecuali untuk depresiasi aset biologis. PT Lonsum melakukan depresiasi atau penyusutan terhadap Tanaman Menghasilkan yang telah mampu memberikan kontribusi manfaat ke dalam perusahaan berupa kemanpuan untuk menghasilkan suatu produk agricultur sedangkan PSAK 69 tidak mengakui adanya penyusutan atas aset biologis.

Penilaian terhadap aset biologis dilakukan pada akhir periode pelaporan untuk memastikan apakah terdapat penurunan nilai maupun nilai terpulihkan. Keuntungan dan kerugian atas penilaian kembali ini diakui pada laporan laba rugi periode berjalan, sesuai dengan PSAK 69 dan dicatat PT Lonsum dengan nama "Rugi yang timbul dari perubahan nilai wajar aset biologis".

\section{Saran}

Mengingat Industri perkebunan merupakan industri yang menjanjikan di Negara Agraris, Indonesia, untuk itu disarankan kepada para akademisi agar menambahkan materi mengenai akuntansi aset biologis kepada mahasiswa khususnya jurusan Akuntansi untuk memperkaya pengetahuan dan sebagai bekal berkarir dikemudian hari. Penelitian ini hanya terbatas pada satu objek penelitian, untuk itu disarankan bagi peneliti selanjutnya untuk menambahkan objek penelitian lebih banyak untuk melihat apakah industri perkebunan secara mayoritas telah menggunakan PSAK 69 seutuhnya. 
ISSN 2657-1080

ISSN 1858-3687

Akuntansi dan Manajemen Vol.14, No.2, 2019

Referensi:

Adnantara, K. Fridagustina. 2013. Pengaruh Struktur Kepemilikan Saham dan Corporate Social Responsibility Pada Nilai Perusahaan. Jurnal Buletin Studi Ekonomi.

Ambarwati, Shinta. 2012. Peraturan dan Regulasi. yang diunduh dari situs http://shintaambarwaty.blogspot.co.id/2012/05/peraturan-dan-regulasibagian-1.html

Amanah,Dian dan Riska. 2015. Analisis Perbandingan Perlakuan Akuntansi Aset biologis pada Industri Perkebunan (Studi Kasus Pada PT Sampoerna Agro,Tbk dan PT Dharma Satya Nusantara Tbk).Artikel. Universitas Brawijaya. Malang.

Bahri, Wahyulia Syafrica. 2015. "Evaluasi Penilaian Aset Biologis Dan Pengaruhnya Terhadap Laporan Keuangan". Artikel. Universitas Jember(UNEJ).Jember BKPM. 2011. Peran Sektor Agrikuktur di Indonesia. Online: www.bkpm.go.id.

Dewi,Ni Wayan dan Gusti Ayu. 2017. Analisis Sitem Akuntansi Aset Biologis Perusahaan Akuakultur (Studi Kasus pada CV dewata Laut). Seminar Nasional Riset Inovatif 2017.

Ghozali, Imam dan Anis Chariri. 2007. Teori Akuntansi. Semarang:Universitas Diponegoro

Hasmi, Nurlaila. 2013. "Penilaian Aset Biologis: Implikasi Penerapan Internasional Accounting Standard (IAS) 41 Pada PT Perkebunan Nusantara XIV Makassar (Persero)". Skripsi. Universitas Islam Negeri (UIN) Alauddin. Makassar

Hui, Freda and G.Bowrey. 2008. "Corporate Social Responsibility Reporting in Hongkong : case Study of Three Note-issuing Bank (2003-2006).

Ikatan Akuntansi Indonesia. 2015. "Pernyataan Standar Akuntansi Keuangan (PSAK) No. 69. Agricultur". Jakarta

Maghfiroh, Siti. Perlakuan Aset Biologis Pada Industri Perkebunan Berdasarkan IAS 41 Agricultured dan PSAK 69 Agrikultur. Studi Pada PT.Perkebunan Nusantara XII (Persero).Surabaya.

Murjoko.2017. Analisis Kinerja Ekspor 5 Komoditas Perkebunan Unggulan Indonesia Tahun 2012-2016.The 5th Urecol Proceeding.Yogyakarta.

Pratiwi, Wike. 2017. Analisis Perlakuan Aset Biologis Berbasis PSAK-69 Agrikultur pada PT.Perkebunan Nusantara XII Kalisanen Kabupaten Jember. Prosiding Seminar Nasional dan CAll For Paper Ekonomi dan Bisnis. Jember

Rianto, Agus Budi Lister. 2012. Analisis Pengakuan, Pengukuran, dan Penyajian Aset Biologis Menurut Standar Akuntansi Yang Berlaku di Indonesia dan Menurut IAS 41: Agricultur ,Studi Kasus PT Kelantara Sakti. Universitas Binus.

Ridwan, Achmad. 2011. Perlakuan Akuntansi Aset Biologis PT. Perkebunan Nusantara XIV Makassar (Persero). Jurnal Makassar: Universitas Hasanuddin.

Suwarto, Yuke Octavianty dan Silvia.2014.Top 15 Tanaman Perkebunan. Jakarta:Penebar Swadaya.

Tang, Qing-wan; Gao, Peng. 2013. Research on Information Disclosure of Biological Assets of Agricultural Listed Company in China. Artikel. Interdisiplinary Journal of Contemporary Research in Business Number 11 Volume 4 March 2013. yang diunduh dari alamat www.ijcrb.webs.com 
ISSN 2657-1080

ISSN 1858-3687

Akuntansi dan Manajemen Vol.14, No.2, 2019

Annual Report PT PP London Sumatera Indonesia,Tbk tahun 2017. yang diunduh dari website http://www.londonsumatra.com/uploads/download/dl47enannualreport $\underline{2}$ 017.pdf 